\title{
Letter \\ A persistently elevated C-reactive protein level in pneumonia may indicate empyema
}

\author{
Michael Eisenhut
}

Luton and Dunstable Hospital, NHS Foundation Trust, Lewsey Road, Luton LU4 ODZ, United Kingdom

Corresponding author: Michael Eisenhut, michael_eisenhut@yahoo.com

Published: 27 February 2008

Critical Care 2008, 12:409 (doi:10.1186/cc6204)

This article is online at http://ccforum.com/content/12/1/409

(c) 2008 BioMed Central Ltd

See related research by Coelho et al., http://ccforum.com/content/11/4/R92

Coelho et al. [1] investigated the use of C-reactive protein (CRP) levels for monitoring of patients with severe community-acquired pneumonia (CAP). They found that patients without a decrease in CRP levels on treatment had an increased mortality compared to patients with a rapid fall of this marker. The authors did not discuss another important use of the analysis of the time course of CRP levels in CAP that applies to patients on both the intensive care unit (ICU) and the general paediatric ward. Empyema fluid has been identified as an important source of CRP in pneumonia [2]. Patients with empyema may have CRP levels of a similar magnitude as the non-survivors in Coelho's study on admission [3]. Adults as well as children who develop empyema were shown to have persistently elevated CRP or a secondary rise of this parameter despite adequate antibiotic treatment $[3,4]$. A persistently elevated or rising CRP level in a patient on the ICU should, therefore, alert the clinician not only to a potentially poor prognosis but also prompt a reassessment of the patient with a chest X-ray and chest ultrasound for the presence of an empyema that may require surgical evacuation.

\section{Authors' reply \\ Luís Coelho and Pedro Póvoa}

We thank Dr Eisenhut for his wise commentary regarding our published manuscript. It represents an important contribution to this discussion.

In our study assessing severe CAP [1], patients whose CRP levels remain elevated, those with non-response and biphasic response patterns, had significantly higher mortality rates. These persistently elevated CRP levels suggest an ongoing inflammatory process that could be associated with a failure of initial antibiotic therapy as well as with a septic complication such as an empyema or an abscess, as $\mathrm{Dr}$ Eisenhut pointed out. Likewise, in our clinical practice, we also found elevated CRP levels in patients with empyema.

Similarly, in a paediatric patient population with pneumococal CAP, Hsieh et al. [5] clearly demonstrated that continuously elevated CRP levels were also associated with necrosis and empyema. Although not specifically studied, we speculate that CRP should present the same time course in patients with ventilator-associated pneumonia complicated with empyema.

As referenced by Dr Eisenhut, Chen et al. [2] found that, in addition to serum CRP, pleural fluid CRP can also be useful in the differentiation of complicated from uncomplicated pleural effusions.

As a result, in patients with persistently elevated or rising CRP levels an aggressive diagnostic and therapeutic approach should be attempted in order to prevent further clinical deterioration and to diagnose potential infectious complications, not only an empyema, as $\mathrm{Dr}$ Eisenhut mentioned, but also other complications, such as acalculous cholecystitis, appendicitis or a catheter-related bloodstream infection.

$\mathrm{CAP}=$ community-acquired pneumonia $\mathrm{CRP}=\mathrm{C}$-reactive protein; $\mathrm{ICU}=$ intensive care unit. 


\section{Competing interests}

The authors declare that they have no competing interests.

\section{References}

1. Coelho L, Povoa P, Almeida E, Fernendes A, Mealha R, Moreira P, Sabino $\mathrm{H}$ : Usefulness of $\mathrm{C}$-reactive protein in monitoring the severe community-acquired pneumonia clinical course. Crit Care 2007, 11:R92.

2. Chen SC, Chen W, Hsu WH, Yu YH, Shih CM: Role of pleural fluid C-reactive protein concentration in discriminating uncomplicated parapneumonic pleural effusions from complicated parapneumonic effusion and empyema. Lung 2006, 84: 141-145.

3. Lahti E, Peltola V, Virkki R, Alanen M, Ruuskanen O: Development of parapneumonic empyema in children. Acta Paediatrica 2007, 96:1686-1692.

4. Icard P, Fleury JP, Regnard JF, Libert JM, Magdeleinat P, Gharbi $\mathrm{N}$, Brachet $\mathrm{A}$, Levi JF, Levasseur P: Utility of C-reactive protein measurements for empyema diagnosis after pneumonectomy. Ann Thorac Surg 1994, 57:933-936.

5. Hsieh YC, Hsueh PR, Lu CY, Lee PI, Lee CY, Huang LM: Clinical manifestations and molecular epidemiology of necrotizing pneumonia and empyema caused by Streptococcus pneumoniae in children in Taiwan. Clin Infect Dis 2004, 38:830-835.

6. Povoa P, Coelho L, Almeida E, Fernandes A, Mealha R, Moreira P, Sabino $\mathrm{H}$ : C-reactive protein as a marker of ventilator-associated pneumonia resolution: a pilot study. Eur Respir J 2005, 25:804-812.

7. Seligman R, Meisner M, Lisboa TC, Hertz FT, Filippin TB, Fachel JM, Teixeira PJ: Decreases in procalcitonin and C-reactive protein are strong predictors of survival in ventilator-associated pneumonia. Crit Care 2006, 10:R125. 